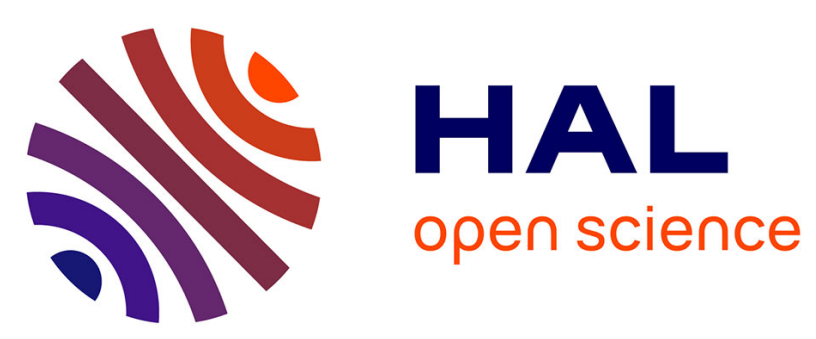

\title{
Genetic characterization of Lithuanian honeybee lines based on ISSR polymorphism
}

\author{
Violeta Ceksteryte, Vanda Paplauskiene, Diana Tamasauskiene, Izolda \\ Pasakinskiene, Ingrida Mazeikiene
}

\section{To cite this version:}

Violeta Ceksteryte, Vanda Paplauskiene, Diana Tamasauskiene, Izolda Pasakinskiene, Ingrida Mazeikiene. Genetic characterization of Lithuanian honeybee lines based on ISSR polymorphism. Apidologie, 2012, 43 (6), pp.652-662. 10.1007/s13592-012-0140-2 . hal-01003662

\section{HAL Id: hal-01003662 https://hal.science/hal-01003662}

Submitted on 1 Jan 2012

HAL is a multi-disciplinary open access archive for the deposit and dissemination of scientific research documents, whether they are published or not. The documents may come from teaching and research institutions in France or abroad, or from public or private research centers.
L'archive ouverte pluridisciplinaire HAL, est destinée au dépôt et à la diffusion de documents scientifiques de niveau recherche, publiés ou non, émanant des établissements d'enseignement et de recherche français ou étrangers, des laboratoires publics ou privés. 


\title{
Genetic characterization of Lithuanian honeybee lines based on ISSR polymorphism
}

\author{
Violeta Ceksteryte ${ }^{1}$, Vanda Paplauskiene ${ }^{1}$, Diana Tamasauskiene ${ }^{1}$, \\ Izolda PASAKINSKIENE ${ }^{2}$, Ingrida MAZEIKIENE ${ }^{3}$

\footnotetext{
${ }^{1}$ Institute of Agriculture, Lithuanian Research Centre for Agriculture and Forestry, 58344 Akademija, Kedainiai distr., Lithuania

${ }^{2}$ Faculty of Natural Sciences, Vilnius University, M. K. Ciurlionio 21/27, 03101 Vilnius, Lithuania

${ }^{3}$ Institute of Horticulture, Lithuanian Research Centre for Agriculture and Forestry, 54333 Babtai, Kaunas reg., Lithuania
}

Received 7 September 2011 - Revised 12 April 2012 - Accepted 26 April 2012

\begin{abstract}
This study presents the first results from the selection and evaluation of inter-simple sequence repeat markers for the genetic assessment of honeybee lines developed in Lithuania and introduced subspecies. Two Lithuania-bred lines of Apis mellifera carnica were compared to those introduced from Czech Republic and Slovenia and also to a subspecies introduced from the Caucasus (Apis mellifera caucasica) and local Buckfast hybrids. The genetic constitution was assayed with four simple sequence primers: (ATG) ${ }_{5} \mathrm{GA}$, $(\mathrm{TCC})_{5} \mathrm{GT},(\mathrm{AGAC})_{4} \mathrm{GC}$ and $(\mathrm{GACA})_{4} \mathrm{GT}$. Trinucleotide motif primers used in the bee DNA assays produced five to 10 fragments and tetranucleotide ones, six to seven. Primer (TCC) $)_{5} \mathrm{GT}$ generated a distinct $A$. $\mathrm{m}$. caucasica-specific 800-bp fragment, which was also present in $40 \%$ of the Buckfast individuals. A dendrogram based on the UPGMS method generated four sub-clusters. One of the Lithuania-bred $A$. m. carnica lines clustered apart from the other $A$. $m$. carnica lines. In a rooted phylogenetic tree, the group containing $A . m$. caucasica and Buckfast hybrids appeared well differentiated from the A. m. carnica lines.
\end{abstract}

\section{honeybee lines / DNA fingerprinting / genetic distance}

\section{INTRODUCTION}

Bees are important pollinators, but recent studies denoted a decline in European bee populations, both in abundance as well as biological diversity (Biesmeijer et al. 2006). The German honeybee monitoring project assessed overwintering mortality of honeybee colonies, and the main causes associated with such losses were high mite Varroa destructor infestation levels, infection with deformed wing virus, acute bee paralysis virus, colony weakness in autumn and also queen age (Genersch et

Corresponding author: V. Ceksteryte, violeta@1zi.lt

Manuscript editor: Klaus Hartfelder al. 2010). The European Union is funding the Prevention of Honey Bee Colony Losses (COLOSS) project and European Cooperation in Science and Technology (COST) Action FA0803, wherein scientists and beekeepers from COST and also some non-COST countries collaborate in complementary research on different aspects of bee health, including the impact of environmental conditions, beekeeping management practices, bee genetic diversity and vitality, among others. The aim of the COLOSS Working Group "Diversity and Vitality" is to reduce the dependency of beekeeping on medication. To accomplish this objective, a total of 670 experimental bee colonies from 17 different genetic origins were distributed over 16 locations across Europe in summer 2009. Chemical 
treatment against mites is prohibited in the test colonies, except for the cases when they are at risk of collapsing. Neighbouring colonies not involved in the experiment can receive chemical treatment against mites. Vitality of bee colonies and infestation level of Varroa mites in the tested colonies will be monitored for several years. This design based on natural selection was proposed to evaluate, select and introduce traits contributing to colony vitality, viz. hygienic behaviour, mite resistance and overwintering (Meixner et al. 2010). A very important trait, fitness of drones under infestation of mites in mating localities, was integrated into the selection process (Büchler et al. 2010). This is of importance as disease resistance is associated with genetic variability of a bee colony (Tarpy and Seeley 2006). Genetic homogeneity due to inbreeding has been shown to lead to a decrease in the innate immune response, as well as many other problems related to bee colony health, like disease transmission, reduced defence against parasites, losses of strength of breeding stocks (Meixner et al. 2010).

The current wide distribution of Carniolan bees over different countries may lead to inbreeding, especially if they are derived from few breeding lines. Nevertheless, several findings suggest natural gene flow among bees or introduction of new strains arriving from different countries. For instance, a restriction site pattern called "eastern Mediterranean type 2" was found in Apis mellifera carnica bees from Austria, Slovenia and Croatia (Meixner et al. 1993; Palmer et al. 2000).

The Caucasian bee, Apis mellifera caucasica, native to Georgia and neighbouring countries, has spread along the Black Sea Coast of Anatolia in Turkey (Ruttner 1988), where it now occurs concomitantly with Apis mellifera anatolica. An intergenic sequence of $A$. $m$. caucasica was described by several authors (Garnery et al. 1992; Smith 1988), and A. m. caucasica bees from Turkey have the highest sequence matches (98-100\%) in locations near Georgia (Palmer et al. 2000).

Commercial beekeeping and the distribution of the valued subspecies A. m. carnica and Apis mellifera ligustica considerably changed the native distribution area of autochthonous subspecies in Europe. In consequence, currently managed populations of European honeybees possess higher genetic similarity to wild African populations (Moritz et al. 2007). On the other hand, losses of genetic diversity due to genetic drift and inbreeding are usually found in small isolated populations, and such losses could increase the risk of extinction by reducing the evolutionary potential to cope with environmental change (Ellstrand and Elam 1993; Frankham 2005).

Conservation genetics studies of bees are particularly important because many bee species are in decline. While beekeepers from Slovenia, Croatia and Serbia take care in maintaining indigenous non-hybridized $A$. $m$. carnica populations (Sušnik et al. 2004), conservation areas for A. m. mellifera and A. m. carnica not always protect the traits of bees indigenous to their area. In Switzerland, special efforts were focused on breeding pure A. m. mellifera and A. $m$. carnica so as to test the level of introgression among populations (SolandReckeweg et al. 2008; Solignac et al. 2003). A. m. mellifera, found in Eastern European countries, including Poland and Belarus close to the southwest of Lithuania's borders (Meixner et al. 2007), was an indigenous population to Lithuania. From 1971 until 1995, this honeybee subspecies was bred in Lithuania in a reservation established in the territory of the JurbarkasTaurage forest area (Balzekas 1995). However, due to its high hybridization level and difficult management, the breeding of Apis mellifera mellifera L. has been discontinued in Lithuania. Current honeybee breeding activity in Lithuania is now focused solely on Carniolan lines, adapted to the climatic conditions and honey flow, and on selection of valuable traits.

Genetic markers defining honeybee lines and subspecies are important tools. For instance, the analysis of mtDNA has become a widely used approach in studying the biogeography according to maternal lineages of honeybees (Garnery et al. 1995). Specific genetic techniques are also used to assess differences among individuals and populations. The relationships between 
population size, loss of genetic diversity and inbreeding in closed random mating populations were also mathematically described by Frankham (2005).

Herein, we used inter-simple sequence repeat (ISSR) markers to reveal genetic variability of $A$. $m$. carnica (Carniolan) lines bred in Lithuania, so as to evaluate their genetic relationship and compare them with other subspecies. As ISSR marker analysis has previously been used in combination with restriction enzyme digestion (ISSR-RFLP) to investigate DNA variation in bees (Sylvester 2003).

\section{MATERIALS AND METHODS}

\subsection{Characterization of honeybee samples}

Samples of Caucasian (A. m. caucasica) and Carniolan (A. m. carnica) bee subspecies and lines for genetic tests were collected from the breeding colonies kept in the apiary of the Institute of Agriculture, Lithuanian Research Centre for Agriculture and Forestry (Institute of Agriculture, LRCAF). The breeding of $A . m$. caucasica bee queens was started at the Institute of Agriculture, LRCAF, from stocks imported from the Russian Institute of Apiculture's bee queen breeding apiary situated in Krasnodar Region, Krasnaja Poliana. The lines $\mathrm{Ct}_{19}$ and $\mathrm{C}_{262}$ of $A$. $m$. carnica subspecies were developed at the Institute of Agriculture, LRCAF, from the $A . m$. carnica lines Singer and Troicek-Singer, imported from Austria in 1998. These lines, $\mathrm{C}_{262}$ and $\mathrm{Ct}_{19}$, are characterised by high honey production, pollen collection and a low swarming rate. A. m. carnica queens of the Vigor line (C Vigor) were brought to the Institute of Agriculture's LRCAF breeding apiary in 2003 from the Czech Institute of Apiculture based in Dole. The bees of this line are resistant to diseases, especially to chalk brood, not prone to excess swarming and noted for high honey production. Queens of the pure A. m. carnica line $\mathrm{Ct}_{19}$ were crossed with Vigor drones. The obtained crosses are marked as $\mathrm{Ct}_{19} \times$ Vigor. A. m. carnica queens were obtained from Slovenia in 2004; subsequently, they are referred to as $C_{\mathrm{SLOV}}$. They are distinguished by very high honey production and good nest cleaning skills; however, they show a high swarming tendency. Buckfast bees were obtained from a local beekeeper, for genetic studies only.

\subsection{DNA isolation, PCR conditions and electrophoresis}

The bee subspecies and lines were represented by 10-12 individuals in the ISSR assays. The bees were placed in 2-mL Eppendorf test tubes and frozen at $-20^{\circ} \mathrm{C}$. DNA was extracted following the CTABbased extraction protocol (Doyle and Doyle 1990) using $750 \mu \mathrm{L}$ of extracting buffer per bee. The DNA concentration was measured spectrophotometrically (Eppendorf BioPhotometer).

Four selected ISSR primers (Metabion, Germany) were used to generate ISSRs: two were of trinucleotide repeats and the other two tetranucleotide repeats (Table I).

The polymerase chain reaction (PCR) assay mixtures $(25 \mu \mathrm{L}$ total volume $)$ consisted of $1 \mu \mathrm{L}$ (50 ng) of genomic DNA, $2.5 \mu \mathrm{L}$ of $10 \times$ DyNAzyme reaction buffer (Finnzymes, Finland), $0.9 \mu \mathrm{L}$ of $\mathrm{MgCl}_{2}(1.8 \mathrm{mM}), 2 \mu \mathrm{L}$ of dNTP $(0.2 \mathrm{mM}), 2.5 \mu \mathrm{L}$ of each primer $(0.25 \mu \mathrm{M})$ and $0.35 \mu \mathrm{L}$ (1.5 units) of

Table I. Characteristics of ISSR primers used for amplification (total, $n=75$ bees).

\begin{tabular}{llcrc}
\hline $\begin{array}{l}\text { ISSR } \\
\text { primer }\end{array}$ & Sequence & $\begin{array}{l}\text { Annealing temp. } \\
\left({ }^{\circ} \mathrm{C}\right)\end{array}$ & $\begin{array}{l}\text { Mean number of amplified } \\
\text { fragments }\end{array}$ & $\begin{array}{l}\text { Fragment size range } \\
(\mathrm{bp})\end{array}$ \\
\hline $\mathrm{GO} 3$ & $(\mathrm{TCC})_{5} \mathrm{GT}$ & 52 & 10 & $500-1,300$ \\
$\mathrm{GO} 8$ & $(\mathrm{ATG})_{5} \mathrm{GA}$ & 52 & 5 & $350-1,400$ \\
$77 \mathrm{H}$ & $(\mathrm{AGAC})_{4} \mathrm{GC}$ & 50 & 7 & $750-3,000$ \\
$104 \mathrm{H}$ & $(\mathrm{GACA})_{4} \mathrm{GT}$ & 50 & 6 & $700-2,000$ \\
\hline
\end{tabular}


DyNAzyme $^{\mathrm{TM}}$ II DNA polymerase (Finnzymes, Finland). Distilled water was added to complete the volume. Twenty-four microlitres of this reaction mixture was added to each sample.

Amplification reactions were performed in an Eppendorf Thermal Cycler (Eppendorf, Germany) under the following conditions: initial denaturation of DNA at $95^{\circ} \mathrm{C}$ for $2 \mathrm{~min}$, followed by 40 cycles consisting of $95^{\circ} \mathrm{C}$ for $30 \mathrm{~s}$, annealing at 45 or $50^{\circ} \mathrm{C}$ for $1 \mathrm{~min}$ depending on the $\mathrm{Tm}$ value of the primer pair, $72^{\circ} \mathrm{C}$ for $30 \mathrm{~s}$ and a final elongation step at $72^{\circ} \mathrm{C}$ for $6 \mathrm{~min}$.

The amplification products were separated by gel electrophoresis on $1.5 \%$ agarose gel in $1 \times \mathrm{TAE}$ buffer and stained with $0.025 \%$ ethidium bromide. GeneRuler TM DNA Ladder Mix (Fermentas) was used as DNA fragment size marker. Reproducibility of the DNA profiles was tested by repeating the PCR amplifications two to three times with each of the respective primers. Electrophoresis was run at $100 \mathrm{~V}$ for $2.5 \mathrm{~h}$. Only the robust and repeatable bands were considered in this study. After electrophoresis, the ISSR patterns of the PCR products were visualized under UV light using a gel documentation system (Bio-Imaging Systems Mini BIS Pro, Israel).

\subsection{Statistical analysis}

The PCR-generated band profiles were scored as presence (1) or absence (0), and obtained data were compiled into a binary matrix. Polymorphism levels (percentage of polymorphic loci-PPL) were expressed as the percentage of the number of polymorphic loci-NPL-against all loci analysed. The data matrix was computed with PopGene 3.2 program to produce genetic distance matrix using the formula of Nei (1978). Genetic relationships among populations were visualized in a dendrogram constructed by unweighted paired group cluster analysis (UPGMA), from a modified NEIGHBOR procedure implemented in PHYLIP and using POPGENE version 3.5 software (dendrogram based on Nei 1978). Computed statistics data of genetic variation for all loci are: observed number of alleles per locus (Na), effective number of alleles (Ne), (Kimura and Crow 1964), Shannon information index (I) (Lewontin 1972), gene diversity $(H)$ (Nei 1973) and PPL. By means of the PopGene program, we calculated total genetic diversity $(\mathrm{Ht})$, genetic diversity within population (Hs) and the proportion of total genetic diversity partitioned among population $G_{\mathrm{ST}}$ (Nei 1987). The estimate of gene flow from $G_{\mathrm{ST}}$ was calculated as $\mathrm{Nm}=0.5\left(1-G_{\mathrm{ST}}\right) / G_{\mathrm{ST}}$ (McDermott and McDonald 1993).

Phylogenetic relationships among bee lines and species were analysed based on the neighbour joining method using the TREECON phylogenetic program (Van de Peer and Wachter 1997). We analysed and computed 500 genetic distance data matrices according to the mathematical model by Nei and Li (1979).

\section{RESULTS}

\subsection{Characterization of DNA fragments generated in polymerase chain reactions}

DNA fragments were amplified with the selected primers listed in Table I. A mean of 28 amplified fragments were scored in the DNA fingerprint profiles representing the two tri- and tetranucleotide motifs. The size of the generated fragments ranged between 350 and 3,000 bp. Twenty five $(89.29 \%)$ of the amplified products were polymorphic. The highest number of fragments in the range 500-1,300 bp was produced with primer $(\mathrm{TCC})_{5} \mathrm{GT}$. The A. m. caucasica subspecies was distinguished from the others by a 350-bp polymorphic fragment, which was amplified with the primer (ATG) ${ }_{5} \mathrm{GA}$ in $90 \%$ of the tested individuals (Figure 1). However, this fragment was not present in the profiles of $A$. $m$. carnica and Buckfast bees. The polymorphic 800bp fragment, specific for A. m. caucasica, was amplified with the primer (TCC) ${ }_{5} \mathrm{GT}$ (Figure 2). No such fragment was obtained in Carniolan bees, but shared in $40 \%$ of the Buckfast individuals. PCR assays with the primer (AGAC) ${ }_{4} \mathrm{GC}$ generated only monomorphic fragments. A. m. caucasica had four non-polymorphic fragments. The DNA fragments amplified with primer (GACA) ${ }_{4}$ GT produced four to six fragments in a narrower range, from 700 to 2,000 bp compared to the ones produced in the assays with the $(\mathrm{AGAC})_{4} \mathrm{GC}$ primer. The primer $(\mathrm{GACA})_{4} \mathrm{GT}$ generated fragments of 700 and $1,900 \mathrm{bp}$, and these were shared by all individuals. 


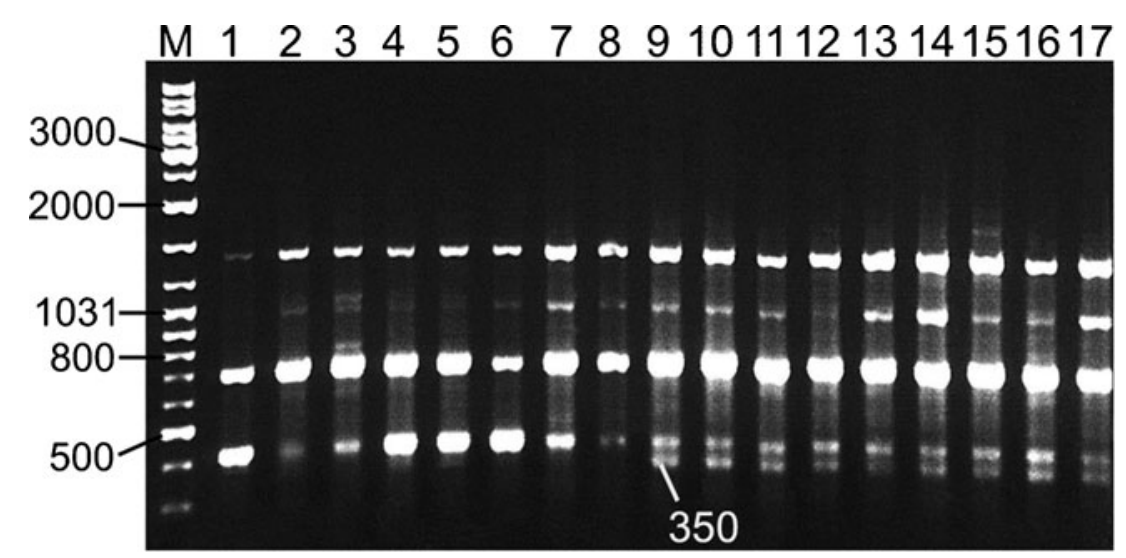

Figure 1. PCR products of bee DNA profiles amplified with the primer (ATG) $)_{5} \mathrm{GA}$ : a) $1-7$ A. m. carnica $\mathrm{C}_{262}$; 8-14 A. m. caucasica; $M$ DNA molecular size marker.

\subsection{Genetic diversity in the populations of $A$. m. carnica A. m. caucasica and Buckfast hybrid bees}

Bee line $\mathrm{Ct}_{19} \times$ Vigor had the lowest percentage of polymorphic loci (28.57\%), with an effective allele number of 1.122 , a Nei's gene diversity of 0.078 and a Shannon's information index of 0.124 (Table II). Analyses done with $A$. $m$. caucasica evidenced the same percentage of polymorphic loci $(28.57 \%)$ as $\mathrm{Ct}_{19} \times$ Vigor. However, the effective number of alleles, Nei's gene diversity and Shannon's information index were higher for $A$. $m$. caucasica, viz. $1.218,0.120,0.173$, respective- ly. The levels of polymorphism of A. m. carnica $\mathrm{Ct}_{19}$ and $\mathrm{C}_{262}$ were higher compared to the other bee lines and subspecies (46.43\%) tested. The two lines differed in effective number of alleles, Nei's gene diversity and Shannon's information index which were higher for line $\mathrm{Ct}_{19}$, amounting to 1.289, $0.167,0.248$, respectively. Nei's gene diversity and Shannon's information index for Buckfast bees were higher than for A. m. caucasica and all lines of Carniolan except for $\mathrm{Ct}_{19}$. The mean value of gene flow (Nm) among populations was 0.6844 , and for $50.0 \%$ of the alleles, it varied at a high range (1.04411.261).

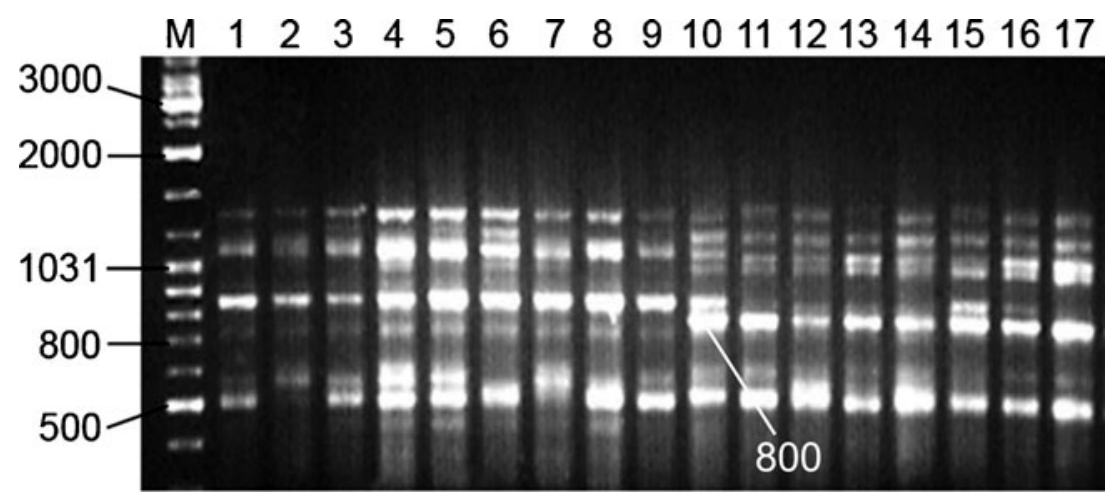

Figure 2. PCR products of bee DNA profiles amplified with the primer (TCC) $)_{5} \mathrm{GT}-1-9$ A. m. carnica $\mathrm{C}_{262}$; 10-17 A. m. caucasica. 
Table II. Genetic variation in bee lines developed in Lithuania compared to introduced subspecies and hybrids ( $n=11$ bees per sample).

\begin{tabular}{lrlllll}
\hline $\begin{array}{l}\text { Bee lines and } \\
\text { subspecies }\end{array}$ & NPL & PPL & Na & Ne & \multicolumn{2}{l}{ I } \\
\hline $\mathrm{C}_{262}$ & 13 & 46.43 & $1.464 \pm 0.508$ & $1.215 \pm 0.345$ & $0.127 \pm 0.182$ & $0.198 \pm 0.260$ \\
A. m. caucasica & 8 & 28.57 & $1.286 \pm 0.460$ & $1.218 \pm 0.375$ & $0.120 \pm 0.200$ & $0.173 \pm 0.285$ \\
$\mathrm{C}$ Vigor & 11 & 39.29 & $1.393 \pm 0.497$ & $1.229 \pm 0.356$ & $0.132 \pm 0.195$ & $0.197 \pm 0.280$ \\
$C_{\text {SLOV }}$ & 10 & 35.71 & $1.357 \pm 0.488$ & $1.209 \pm 0.338$ & $0.123 \pm 0.186$ & $0.185 \pm 0.269$ \\
$\mathrm{Ct}_{19}$ & 13 & 46.43 & $1.464 \pm 0.508$ & $1.289 \pm 0.375$ & $0.167 \pm 0.204$ & $0.248 \pm 0.293$ \\
$\mathrm{Ct}_{19} \times$ Vigor & 8 & 28.57 & $1.286 \pm 0.460$ & $1.122 \pm 0.248$ & $0.078 \pm 0.144$ & $0.124 \pm 0.217$ \\
$\mathrm{Buckfast}_{\text {Mean }}$ & 12 & 42.86 & $1.429 \pm 0.504$ & $1.254 \pm 0.353$ & $0.150 \pm 0.194$ & $0.226 \pm 0.282$ \\
& 10.7 & $38.27 \pm 2.89$ & $1.380 \pm 0.030$ & $1.220 \pm 0.020$ & $0.130 \pm 0.010$ & $0.190 \pm 0.010$
\end{tabular}

$N P L$ number of polymorphic loci, $P P L$ percentage of polymorphic loci, $N a$ observed number of alleles per locus, $N e$ effective number of alleles, $I$ Shannon information index, $H$ gene diversity

\subsection{Genetic structure within bee subspecies and lines}

The mean coefficient of gene differentiation $G_{\mathrm{ST}}$ calculated from the 75 individuals was 0.422 , with a range from 0.0425 to 0.8845 , showing that differentiation among populations was generally low to moderate. The highest $G_{\mathrm{ST}}$ values of 0.827 and 0.8845 were obtained only in two cases. Mean gene diversity (Ht) and gene diversity within populations (Hs) were 0.222 and 0.422 , respectively.

The genetic distance was calculated from 28 amplified bands. For each sample, ISSR bands were scored as 1 (present) or 0 (absent), and these binary data were entered into a rectangular matrix. A. m. carnica line C Vigor was identical to $C_{\mathrm{SLOV}}$ and $\mathrm{Ct}_{19}$ in terms of genetic identity, which was highest $(0.9632)$ between $C$ Vigor and $C_{\mathrm{SLOV}}$, and slightly lower between $\mathrm{C}$ Vigor and $\mathrm{Ct}_{19}$ 0.9543. Nei's genetic distance value was highest between pairs of Buckfast with $\mathrm{C}_{262}$ and $A$. m. caucasica with $\mathrm{C}_{262}$, being 0.1986 and 0.1910 , respectively (Table III). The lowest genetic distance of 0.0375 was found between $C_{\text {SLOV }}$ and $\mathrm{C}$ Vigor. Use of the UPGMA algorithm permitted clustering the data and inferring a relationship among bee lines and species tested (Figure 3). The dendrogram shown in Figure 3 represents the genetic divergence of the A. m. caucasica subspecies and Buckfast hybrids from the Carniolan lines tested. The various A. m. carnica lines were grouped in two sub-clusters. The first one consisted of the Carniolan bee line $\mathrm{C}_{262}$. The separate clustering of line $\mathrm{C}_{262}$ from the other $A$. $m$. carnica lines indicated their within population genetic diversity. The second subcluster was composed of two introduced Carniolan bee lines, $\mathrm{C}$ Vigor and $C_{\mathrm{SLOV}}$ and $\mathrm{Ct}_{19}$ both developed in Lithuania. The cluster shows a close similarity between the two breeding lines C Vigor and $C_{\text {SLOV. }}$. Buckfast hybrids were in the subcluster with the cross of $\mathrm{Ct}_{19} \times \mathrm{C}$ Vigor. The Carniolan bee lines $\mathrm{C}$ Vigor and $C_{\mathrm{SLOV}}$, as well as Buckfast hybrids and $\mathrm{Ct}_{19} \times \mathrm{C}$ Vigor, were shown to be genetically closest. A. m. caucasica was clearly separated from the Buckfast and Carniolan bee lines, confirming the genetic differences.

\subsection{Phylogenetic analysis}

A bootstrap analysis was performed to assess significant genetic differences between the tested bee lines and subspecies obtained from the ISSR data (Figure 4). The values shown on the branches indicate significant differences (higher than $50.0 \%$ ) among bee lines and subspecies. The highest significant bootstrap value was between $A$. m. caucasica species and Buckfast hybrids, the lowest value between 
Table III. Genetic identity (above diagonal) and genetic distance (below diagonal) of investigated bee subspecies and lines, calculated according to Nei (1978) implemented in PopGene of PHYLIP Version $3.5(n=$ 11 bees per sample).

\begin{tabular}{llllllll}
\hline $\begin{array}{l}\text { Bee lines and } \\
\text { subspecies }\end{array}$ & $\mathrm{C}_{262}$ & $\begin{array}{l}\text { A. } m . \\
\text { caucasica }\end{array}$ & $\begin{array}{l}\mathrm{C} \\
\text { Vigor }\end{array}$ & $C_{\mathrm{SLOV}}$ & $\mathrm{Ct}_{19}$ & $\begin{array}{l}\mathrm{Ct}_{19} \times \\
\text { Vigor }\end{array}$ & Buckfast \\
\hline $\mathrm{C}_{262}$ & $\mathbf{1 . 0 0 0 0}$ & 0.8261 & 0.8979 & 0.9080 & 0.9319 & 0.8647 & 0.8199 \\
A. m. caucasica & 0.1910 & $\mathbf{1 . 0 0 0 0}$ & 0.8484 & 0.8098 & 0.8446 & 0.8095 & 0.8681 \\
$\mathrm{C}$ Vigor & 0.1077 & 0.1644 & $\mathbf{1 . 0 0 0 0}$ & 0.9632 & 0.9543 & 0.8988 & 0.8454 \\
$C_{\text {SLOV }}$ & 0.0965 & 0.2109 & 0.0375 & $\mathbf{1 . 0 0 0 0}$ & 0.9416 & 0.9127 & 0.8563 \\
$\mathrm{Ct}_{19}$ & 0.0705 & 0.1689 & 0.0468 & 0.0602 & $\mathbf{1 . 0 0 0 0}$ & 0.9063 & 0.8658 \\
$\mathrm{Ct}_{19} \times$ Vigor & 0.1454 & 0.2113 & 0.1067 & 0.0913 & 0.0984 & $\mathbf{1 . 0 0 0 0}$ & 0.9348 \\
Buckfast & 0.1986 & 0.1414 & 0.1679 & 0.1551 & 0.1441 & 0.0674 & $\mathbf{1 . 0 0 0 0}$ \\
\hline
\end{tabular}

Bold 1.000 indicates the relationship between the two identical individuals, and this value separates the table of the diagonal into two parts

$C_{\text {SLOV }}$ and $\mathrm{C}$ Vigor. The bootstrap value also showed that $\mathrm{Ct}_{19}$ significantly differed from all Carniolan lines, as well as A. m. caucasica and Buckfast hybrids.

\section{DISCUSSION}

Mitochondrial DNA (mtDNA) has frequently been used to group bees within the previously classified evolutionary lineages (Ruttner et al. 1978; Ruttner 1988). The mitochondrial genome of $A$. m. ligustica was sequenced in 1993 (Crozier and Crozier 1993), showing a total length of $16,343 \mathrm{bp}$. The intergenic region of the mtDNA COI-COII genes with tRNE ${ }^{\text {leu }}$ and non-coding sequence with two elements $\mathrm{P}$ and
Q is polymorphic revealing the lineages from which bees are derived (Garnery et al. 1992; Nikonorov et al. 1998). These findings had applications in the identification of bees of European and African origin according to maternal lineages and allowed detection of the level of population hybridization and gene flow within population (Hall and Muralidharan 1989).

In contrast, microsatellite markers are used to evaluate introgressive hybridization through mating between drones and queens (De la Rúa et al. 2009). Microsatellites occur everywhere in the genome (both in nuclear and organellar DNA) and are found in all known living organisms. Microsatellites are short, 2- to 6bp-long tandem repeats, dispersed throughout the nuclear genome (Sheppard and Smith 2000).

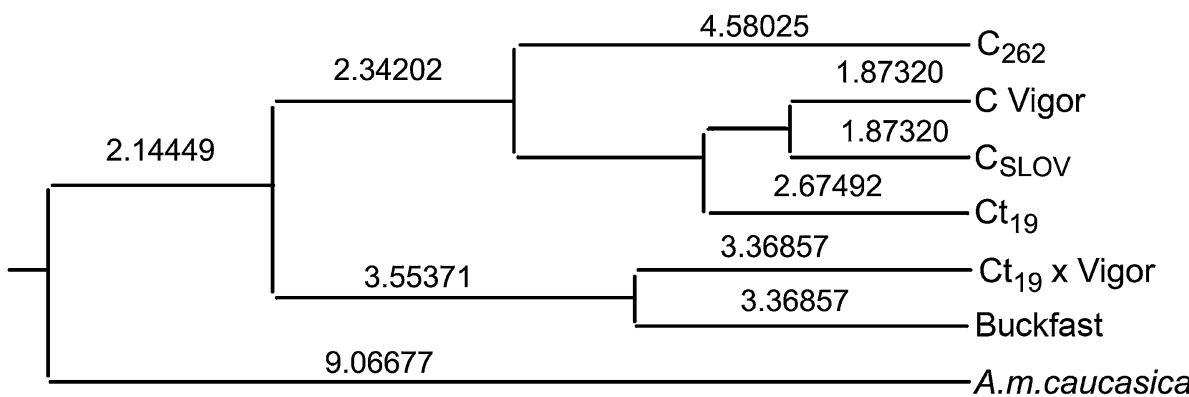

Figure 3. Genetic distance between bee lines and species. Dendrogram based on Nei's (1978) genetic distance (PopGene program UPGMA PHYLIP Version 3.5, modified NEIGHBOR method). 


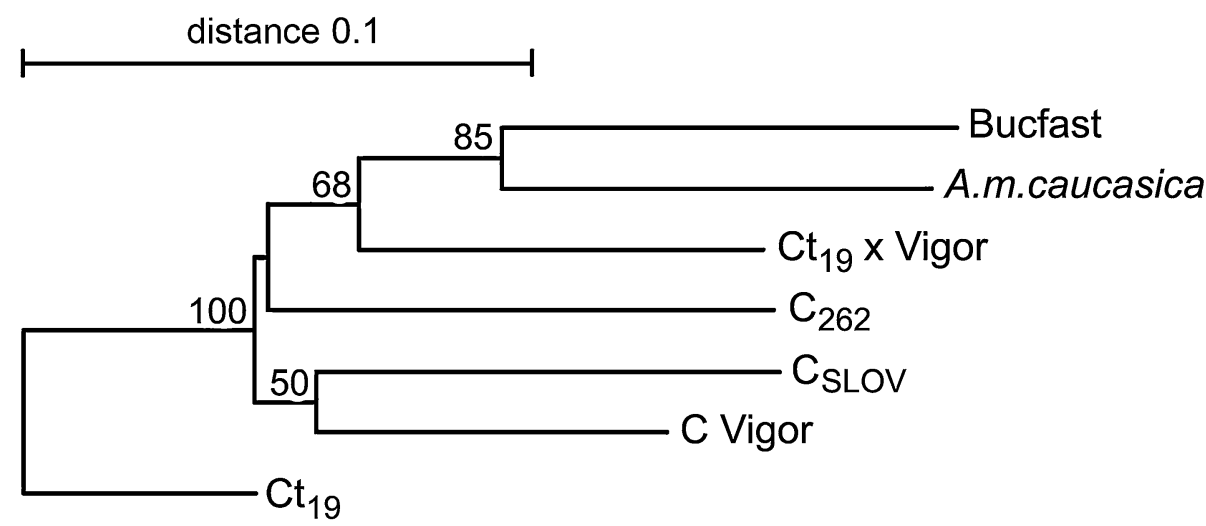

Figure 4. Phylogenetic relationships among A. m. caucasica, Buckfast and Carniolan honeybee populations based on the neighbour joining method. The tree was constructed with the TREECON phylogenetic program (Van de Peer and Wachter 1997). The genetic distance data matrix was calculated using the formula of Nei and Li (1979).

In collaborative investigations, 552 microsatellites were sequenced, and many of them were amplified in other Apis species, viz.: Apis cerana (58 \%), Apis dorsata (59\%) and Apis florea (38\%). The variability of 36 loci in the three main evolutionary lineages of $A$. mellifera was also evaluated (Solignac et al. 2003). Microsatellites are abundant in the genome of the honeybee and have been used to create a linkage map of $A$. mellifera L. (Solignac et al. 2004). Microsatellite markers have long been used for genetic analyses of bees (Estoup et al. 1993; 1995; Oldroyd et al. 1994). The Apis genome carries more than $60 \%$ of the total microsatellites in coding region; $50 \%$ tri- and $25 \%$ dinucleotide repeats are present in exonic regions (Archak et al. 2007).

Variation in repeat numbers, an important characteristic of microsatellites, has been exploited extensively as genetic markers, and most of the microsatellite databases offer specific marker information of microsatellite loci. The application of microsatellite markers is furthermore helpful for examining population density and decline (Paini 2004), conservation genetics, (Haig 1998; Solignac et al. 2003), introduction of foreign subspecies (Bodur et al. 2007), as well as for revealing relationships among individuals, population genetic structure analysis (Shaibi et al. 2008).
The first application of ISSR markers was carried out in 1994 (Zietkiewicz et al. 1994) for a plant genetics study, and they are now extensively used for the evaluation of plant hybridization, diploid hybrid speciation and cultivar identification (Paplauskiene et al. 2007; Pivoriene and Pasakinskiene 2008). ISSRs are a 100 - to 3,000-bp genomic region between two identical inverted microsatellite loci (Gupta et al. 1994). Amplification products of such regions are obtained with single primers $16-18 \mathrm{bp}$ in length, having 3 '-anchoring or 5'anchoring nucleotides or are non-anchored primers. An anchored primer typically has two to four anchoring nucleotides. Appropriate genomic templates for PCR amplification are situated between inversely oriented microsatellites (Bornet et al. 2002). While initially developed to study plant cultivars, ISSR markers have also been successfully adapted for use in genetic studies of insects, e.g. Diptera (Culicidae, Tachinidae), Lepidoptera, Hemiptera and Hymenoptera, all revealing differences among species (Awasthi et al. 2004; Korbin et al. 2002; Martins-Lopes et al. 2007). The genetic diversity between and within species of blackflies was revealed with the ISSR markers (Dušinsky et al. 2006), and inter-specific genetic variation was found in five species of bumblebee (Berezovskaja et al. 2002). Notwith- 
standing, ISSR markers are still rarely applied in bee genetic studies.

Herein, we used ISSR markers to determine similarities and differences within the bee lines and subspecies in Lithuania, providing information on genetic identity and gene flow among lines and subspecies. While breeders of honeybee queens are generally not in a position to estimate the impact of the gene pool of different bee lines and subspecies based only on assessment of external morphology, our study could elucidate the relationships among the $\mathrm{Ct}_{19}$ and $\mathrm{C}_{262}$ lines, both developed from pure Carniolan bee queens, with Caucasian bees (A. m. caucasica), and Buckfast hybrids introduced to Lithuania.

The Carniolan bee line $\mathrm{Ct}_{19}$ showed the highest values in the effective number of alleles, Nei's gene diversity and Shannon's information index compared to $\mathrm{C}_{262}$ and Carniolan bees introduced to Lithuania, and to A. m. caucasica and Buckfast hybrids. Our findings furthermore suggest that the locally developed Carniolan bee lines $\mathrm{Ct}_{19}$ and $\mathrm{C}_{262}$ significantly differ from the introduced lines $C$ Vigor and $C_{\text {SLOV }}$. The Carniolan bee line $\mathrm{C}_{262}$ clustered separately in the dendrogram, inferring their genetic diversity. Conversely, the close similarity observed between the two lines $\mathrm{C}$ Vigor and $C_{\text {SLOV }}$ suggests a possibility to prevent their crossing and inbreeding.

The high rate of gene flow inferred herein within the population of our tested bee lines and subspecies suggests that no appropriate measures were taken to prevent inbreeding. Another factor probably responsible for this fact is that only a small number of pure breeding lines were used. With the development of the Lithuanian bee lines, we expect that this situation can be corrected. Furthermore, we propose that ISSR assaying can be implemented as a powerful tool for the assessment of genetic differences among honeybee species, subspecies and breeding lines.

\section{ACKNOWLEDGMENTS}

The authors kindly acknowledge the support of the Lithuanian Ministry of Agriculture provided to this study, as well as those who assisted in this project.
Caractérisation génétique des lignées d'abeilles de Lithuanie basée sur le polymorphisme ISSR

Lignées d'abeilles / distance génétique / empreinte génétique

Genetische Charakterisierung von Bienenlinien in Litauen basierend auf IRRS Polymorphismus

Schlüsselwörter: Honigbienen-Linien / DNA Fingerabdrücke / Genetische Distanzen

\section{REFERENCES}

Archak, S., Meduri, E., Sravana Kumar, P., Nagaraju, J. (2007) InSatDb: a microsatellite database of fully sequenced insect genomes. Nucleic Acids Res. 35 (Database issue), D36-D39

Awasthi, A.K., Nagaraja, G.M., Naik, G.V., Kanginakudru, S., Thangavelu, K., Nagaraju, J. (2004) Genetic diversity and relationships in mulberry (genus Morus) as revealed by RAPD and ISSR marker assays. BMC Genet. 5, e1

Balzekas, J.A. (1995) The preservation of native bees in Lithuania. Zemdirbyste 42, 9-20

Berezovskaja, P.P., Moroz, O.Iu., Sidorenko, A.P. (2002) Intra- and interspecies differences in the ISSR PCR patterns of bumble bee (Hymenoptera: Bombinae). Tsitol. Genet. 36, 28-35

Biesmeijer, J.C., Roberts, S.P.M., Reemer, M., Ohlemüller, R., Edwards, M., Peeters, T., Schaffers, A.P., Potts, S.G., Kleukers, R., Thomas, C.D., Settele, J., Kunin, W.E. (2006) Parallel declines in pollinators and insectpollinated plants in Britain and the Netherlands. Science 313, 351-354

Bodur, C., Kence, M., Kence, A. (2007) Genetic structure of honeybee, Apis mellifera L. (Hymenoptera: Apidae) populations of Turkey inferred from microsatellite analysis. J. Apic. Res. 46, 50-56

Bornet, B., Muller, C., Paulus, F., Branchard, M. (2002) Highly informative nature of inter simple sequence repeat (ISSR) sequences amplified using tri- and tetranucleotide primers from DNA of cauliflower (Brassica olerace var. botyris L.). Genome 45, 890-896

Büchler, R., Berg, S., Conte, Y. (2010) Breeding for resistance to Varroa destructor in Europe. Apidologie 41, 393-408

Crozier, R.H., Crozier, Y.C. (1993) The mitochondrial genome of the honey bee Apis mellifera, complete sequence and genome organization. Genetics 133, 97-117

De la Rúa, P., Jaffé, R., Dall'Olio, R., Muñnoz, I., Serrano, J. (2009) Biodiversity, conservation and current threats to European honeybees. Apidologie 40, 263-284 
Doyle, J.J., Doyle, J.L. (1990) Isolation of plant DNA from fresh tissue. Focus 12, 13-15

Dušinsky, R., Kudela, M., Stloukalova, V., Jedlička, L. (2006) Use of inter-simple sequence repeat (ISSR) markers for discrimination between and within species of blackflies (Diptera: Simuliidae). Biologia 61, 299-304

Ellstrand, N.C., Elam, D.R. (1993) Population genetic consequences of small population size: implications for plant conservation. Annu. Rev. Ecol. Syst. 24, 217-242

Estoup, A., Solignac, M., Harry, M., Cornuet, J.M. (1993) Characterization of (GT)n and (CT)n microsatellites in two insect species: Apis mellifera and Bombus terrestris. Nucleic Acids Res. 21(6), 1427-1431

Estoup, A., Garnery, L., Solignac, M., Cornuet, J.M. (1995) Microsatellite variation in honey bee (Apis mellifera L.) populations: hierarchical genetic structure and test of the infinite allele and stepwise mutation models. Genetics 140, 679-695

Frankham, R. (2005) Genetics and extinction. Biol. Conserv. 126, 131-140

Garnery, L., Cornuet, J.-M., Solignac, M. (1992) Evolutionary history of the honey bee Apis mellifera inferred from mitochondrial DNA analysis. Mol. Ecol. 1, 145-154

Garnery, L., Mosshine, E.H., Oldroyd, B.P., Cornuet, J.M. (1995) Mitochondrial DNA variation in Moroccan and Spanish honey bee populations. Mol. Ecol. 4(4), 465-472

Genersch, E., Ohe, W., Kaatz, H., Schroeder, A., Otten, Ch, Büchler, R., Berg, S., Ritter, W., Mühlen, W., Gisder, S., Meixner, M., Liebig, G., Rosenkranz, P. (2010) The German bee monitoring project: a long term study to understand periodically high winter losses of honey bee colonies. Apidologie 41, 332-352

Gupta, M., Chyi, Y.-S., Romero-Severson, J., Owen, J.L. (1994) Amplification of DNA markers from evolutionarily diverse genomes using single primers of simple-sequence repeats. Theor. Appl. Genet. 89(78), 998-1006

Haig, S.M. (1998) Molecular contributions to conservation. Ecology 79, 413-425

Hall, H.G., Muralidharan, K. (1989) Evidence from mitochondrial DNA that African honey bees spread as continuous maternal lineages. Nature 339, 211-213

Kimura, M., Crow, J.F. (1964) The number of alleles that can be maintained in a finite population. Genetics 49, 725-738

Korbin, M., Kuras, A., Zurawicz, E. (2002) Fruit plant germplasm characterisation using molecular markers generated in RAPD and ISSR-PCR. Cell. Mol. Biol. Lett. 7, 785-794

Lewontin, R.C. (1972) The apportionment of human diversity. Evol. Biol. 6, 381-398

Martins-Lopes, P., Lima-Brito, J., Gomes, S., Meirinhos, J., Santos, L., Guedes-Pinto, H. (2007) RAPD and
ISSR molecular markers in Olea europea L.: genetic variability and molecular cultivar identification genetic. Genet. Resour. Crop Evol. 54, 117-128

McDermott, J.M., McDonald, B.A. (1993) Gene flaw in plant pathosystems. Annu. Rev. Phytopathol. 31, 353-373

Meixner, M.D., Sheppard, W.S., Poklukar, J. (1993) Asymetrical distribution of mitochondrial DNA polymorphism between 2 introgressing honey bee subspecies. Apidologie 24, 147-153

Meixner, M.D., Worobik, M., Wilde, J., Fuchs, S., Koeniger, N. (2007) Apis mellifera mellifera in eastern Europe-morphometric variation and determination of its range limits. Apidologie 38, 191-197

Meixner, M.D., Costa, C., Kryger, P., Hatjina, F., Bouga, M., Ivanova, E., Büchler, R. (2010) Conserving diversity and vitality for honey bee breeding. J. Apic. Res. 49, 85-92

Moritz, R.F., Kraus, F.B., Kryger, P., Crewe, R.M. (2007) The size of wild honeybee populations (Apis mellifera) and its implications for the conservation of honeybees. J. Insect Conserv. 1, 391-397

Nei, M. (1973) Analysis of gene diversity in subdivided population. Proc. Natl. Acad. Sci. U.S.A. 70, 33213323

Nei, M. (1978) Estimation of average heterozygosity and genetic distance from a small number of individuals. Genetics 89, 583-590

Nei, M. (1987) Molecular evolutionary genetics. Columbia University Press, New York

Nei, M., Li, W.H. (1979) Mathematical model for studying genetic variation in terms of restriction endonucleases. Proc. Natl. Acad. Sci. U.S.A. 76, 5269-5273

Nikonorov, Yu.M., Ben'kovskaya, G.V., Poskryakov, A.V., Nikolenko, A.G., Vakhitov, V.A. (1998) The use of the PCR technique for control of the purebreeding of honeybee (Apis mellifera mellifera L.) colonies from the southern Urals. Genetika 34, 1574-1577

Oldroyd, B.P., Smolenski, A.J., Cornuet, J.-M., Crozier, R.H. (1994) Anarchy in the beehive. Nature 371, 749

Paini, D.R. (2004) Impact of the introduced honey bee (Apis mellifera) (Hymenoptera: Apidae) on native bees: A review. Austral Ecol. 29, 399-407

Palmer, M.R., Smith, D.R., Kaftanoglu, O. (2000) Turkish honey bees: genetic variation and evidence for a fourth lineage of Apis mellifera mtDNA. J. Hered. 91, 42-46

Paplauskiene, V., Dabkeviciene, G., Pasakinskiene, I. (2007) Molecular characterization of interspecific clover hybrids using ISSR markers. Zemdirbyste 94, 111-119

Pivoriene, O., Pasakinskiene, I. (2008) Genetic diversity assessment in perennial ryegrass and Festulolium by ISSR fingerprinting. Zemdirbyste 95, 125-133 
Ruttner, F. (1988) Biogeography and Taxonomy of Honeybees. Springer, Berlin Heidelberg

Ruttner, F., Tassencourt, L., Louveaux, J. (1978) Biometrical-statistical analysis of the geographic variability of Apis mellifera L. Apidologie 9, 363381

Shaibi, T., Lattorff, H.M.G., Moritz, R.F.A. (2008) A microsatellite DNA toolkit for studying population structure in Apis mellifera. Mol. Ecol. Resour. 8, 1034-1036

Sheppard, W.S., Smith, D.R. (2000) Identification of African-derived bees in the Americas: a survey of methods. Ann. Entomol. Soc. Am. 93(2), 159-176

Smith, D.R. (1988) Mitochondrial DNA polymorphism in five Old World subspecies of honey bees and in New World hybrids. In: Needham, G.R., Page Jr., R.E., Delfinado-Baker, M., Bowman, C.E. (eds.) Africanized honey bees and bee mites, pp. 303-312. Ellis Horwood, Chichester

Soland-Reckeweg, G., Heckel, G., Neumann, P., Fluri, P., Excoffier, L. (2008) Gene flow in admixed populations and implications for the conservation of the Western honeybee, Apis mellifera. J. Insect Conserv. 13(3), 317-328

Solignac, M., Vautrin, D., Loiseau, A., Mougel, F., Baudry, E., Estoup, A., Garnery, L., Haberl, M.,
Cornuet, J.-M. (2003) Five hundred and fifty microsatellite markers for the study of the honeybee (Apis mellifera L.) genome. Mol. Ecol. Notes 3, 307-311

Solignac, M., Vautrin, D., Baudry, E., Mougel, F., Loiseau, A., Cornuet, J.-M. (2004) A microsatellite-based linkage map of the honeybee, Apis mellifera L. Genetics 167, 253-262

Sušnik, S., Kozmus, P., Poklukar, J., Meglic, V. (2004) Molecular characterisation of indigenous Apis mellifera carnica in Slovenia. Apidologie 35, 623-636

Sylvester, H. (2003) Inter-simple sequence repeatrestriction fragment length polymorphism for DNA fingerprinting. Biotechniques 34(5), 942-944

Tarpy, D.R., Seeley, T.D. (2006) Lower disease infections in honeybee (Apis mellifera) colonies headed by polyandrous vs monandrous queens. Naturwissenschaften 93, 195-199

Van de Peer, Y., Wachter, D. (1997) Construction of evolutionary distance trees with TREECON for Windows: accounting for variation in nucleotide substitution rate among sites. Comput. Appl. Biosci. 13, 227-230

Zietkiewicz, E., Rafalski, A., Labuda, D. (1994) Genome fingerprinting by simple sequence repeat (SSR)anchored polymerase chain reaction amplification. Genomics 20, 176-183 